\title{
Introduction to the Research Handbook of Women's Entrepreneurship and Value Creation
}

\author{
Shumaila Yousafzai, Colette Henry, Monique Boddington, \\ Shandana Sheikh and Alain Fayolle
}

Entrepreneurship is a multi-faceted concept in which several factors, including the entrepreneurial context, the individual entrepreneur, the entrepreneurial environment, and the entrepreneurial product or service, combine to create the outcomes of the entrepreneurial process. Entrepreneurial outcomes have been mostly studied in terms of financial performance, wealth creation, firm survival, improvement in the quality of life (McMullen and Warnick, 2015), and promotion of economic growth in developed and developing economies and across industries (Audretsch et al., 2006; Baumol, 1986). Although evaluation of entrepreneurial activity in these terms is important, it often results in a one-sided analysis in which entrepreneurship is evaluated and appraised solely in monetary terms, without reference to its social impact (Zahra et al., 2009), that is, without mention of other kinds of value that come from it. Although, the focus on financial outcomes excludes social entrepreneurship, which is based primarily on fulfilling a community's unmet needs and creating social value. Nevertheless, restricting the discussion of non-monetary value creation in entrepreneurship to social entrepreneurs further limits the full scope of value created by all entrepreneurs, not just social entrepreneurs. It also limits the contribution of entrepreneurial activity that is initiated by disadvantaged and marginalized groups like women, ethnic minorities, the disabled, and youth (Welter, 2011), even though these groups often create significant value beyond financial value. Such value takes multiple forms and occurs at various levels, so it must be documented if the full contribution that entrepreneurs make to the economy and society is to be recognized.

This edited volume aims to present a collection of studies that would further explore, rethink, and recognize the value created through women's entrepreneurship and will co-create useful knowledge and expertise that can feed joint learning, innovative practices and evidence-based policy-making for successful women's entrepreneurship promotion and gender-just inclusive growth around the globe. Such studies would highlight the importance of women as agents of change for society and the economy and would have important implications for policy-making in that they would direct attention to and provide evidence for the positive contribution of women entrepreneurs to the economy, regardless of their businesses' size and formal status, thus, acknowledging women entrepreneurs' efforts and supporting their value-creation activities. Through these studies, we hope that the researchers 
would challenge the underperformance hypothesis associated with women entrepreneurs and present evidence that women do not underperform in their businesses but that they add value, even in constrained environments. The chapters that we seek to include in the edited volume may direct future researchers to shift the focus of research from questions like "what do entrepreneurs do?" to "how do they do it?" (in order to focus on the unique ways in which each woman entrepreneur creates value), and "for whom do they do it?" (in order to focus on the multiple value outcomes women entrepreneurs create and the beneficiaries of that value) (Zahra et al., 2009). Figure I.1 illustrates some examples of the multiplicity of value creation that this edited volume aims to explore in the context of women's entrepreneurship.

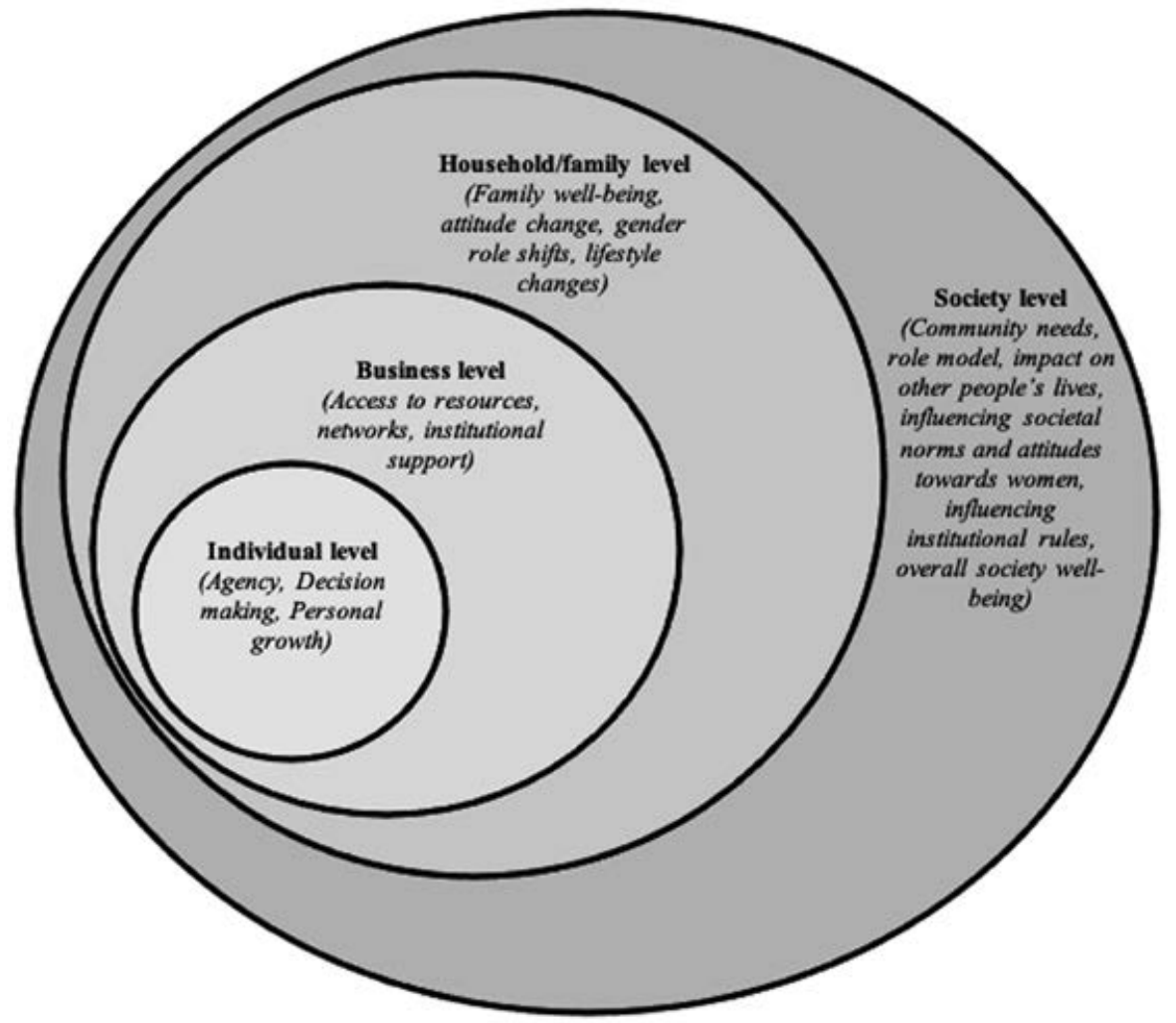

Source: Authors.

Figure I.1 Multiple levels of value creation through women's entrepreneurial activity

Although women entrepreneurs are often seen as the rising stars of the economy (Vossenberg, 2013) and the way forward (World Economic Forum, 2012), the 
disconnect between the performance of women-owned enterprises compared to those of their male counterparts still holds (Ahl, 2006; Marlow et al., 2008; Powell and Eddleston, 2008) largely because of an inequitable performance evaluation that disregards value-related outcomes beyond the financial that accrue at multiple levels and have a long-term impact on the creators (women entrepreneurs) of this value, as well as on the recipients who are affected by it. We acknowledge that it is difficult to define the multiple realms of value that result from women's entrepreneurial activity (WEA), as entrepreneurs and their contexts differ widely. Nevertheless, scholars have suggested that the extent to which the value from an entrepreneurial venture is created depends on the concept (i.e., the business idea), the resources available, and the ability and the skills of the entrepreneur to execute and implement the idea (Zahra et al., 2009). Therefore, we argue that not all entrepreneurs are cut out for or aspire to high growth and performance. While women entrepreneurs are often labelled "underperformers" in business for low growth and low success rates, and are, therefore, under-recognized in the sphere of value creation, these criteria are what society expects women to achieve, not necessarily what women themselves expect or want to achieve.

\section{THE CHAPTERS IN THIS VOLUME}

In response to the limitation in the current entrepreneurial literature regarding the full impact of and value creation through women's entrepreneurial activity, we seek to fill part of the resulting gap by inviting researchers to take a woman's perspective on value creation in entrepreneurship and explore the lived experiences of women entrepreneurs by documenting the value they create across various frontiers. We invited researchers to study performance and success from a woman's perspective and acknowledge that these women may not have high profit margins but may be satisfied with the balance between their businesses and personal lives; they may not have high-tech firms or a physical presence on the high street but may contribute to their families' and households' needs and wants. Hence, we asked the researchers to look beyond standard measures of performance and success and focus on what success and performance means to the woman entrepreneur. Each woman has her own story and offers her own unique value to add to her entrepreneurial environment. This edited volume called for opening the debate on women as creators of value in entrepreneurship and encourages researchers to advance this debate by exploring unconventional value outcomes in multiple contexts, business sectors, industries, and countries. This approach also called for challenging the "otherness" of women entrepreneurs as inferior, not fit for business, and underperforming.

This refocusing will help to cultivate a debate that emphasizes social capital as an enabling resource, the social environment as a context, and social benefit as an outcome of any type of entrepreneurial activity. Evaluating the outcome dimension with a social lens across various forms of entrepreneurship facilitates a multi-dimensional analysis of the growth and performance of women entrepre- 
neurs' enterprises (Korsgaard and Anderson, 2011). This line of research has the potential to initiate a break from dominant methods of positivistic research to more exploratory ones that involve qualitative techniques that help to capture the real impact of entrepreneurship at multiple levels. Our goal is to co-create expertise that can feed joint learning, innovative practices and evidence-based policy-making for the gender-just promotion of women's entrepreneurship promotion and inclusive growth around the globe. In doing so, we highlight what influences and restrains the growth of women's entrepreneurship and offer useful insights into women's entrepreneurship as they apply to specific contexts.

In particular, contributions were sought from researchers in geographic regions that are not sufficiently represented in the women's entrepreneurship literature. We received chapters based on data from Afghanistan, Canada, Ethiopia, Guatemala, Honduras, India, Iran, Ireland, Kenya, Mexico, Nepal, Norway, Pakistan, Palestine, Saudi Arabia, South Africa, Sweden, Uganda, United Kingdom, USA and multi-country studies based on the Global Entrepreneurship Monitor (GEM) dataset. Collectively, these studies make a substantial contribution to the value creation literature through women's entrepreneurial activity, provide numerous insights and provoke fruitful directions for future research on the important role of the context in which women's entrepreneurial activity takes place.

\section{Part I: Value Creation at the Individual Level}

Despite the barriers faced by women and the constraints on their performance and growth in business, entrepreneurship may not only give women independence to follow their career choices but also empower them with control over their wealth, assets and decisions regarding this wealth, which can promote their personal growth and development and improve their overall well-being and quality of life (Beath et al., 2013; Haneef et al., 2014; Haugh and Talwar, 2014; Kantor, 2003). Value accumulated from increased agency at the individual level can contribute to elevating women's status in their entrepreneurial environment and to building positive self-perceptions among them.

In Part I we wish to represent and encourage broader engagement with the aspects of value creation at the individual level that are due to a women's engagement in entrepreneurial activity. This broader engagement will illustrate the diversity of thought that has yet to be applied to the ideas of value creation at the individual level. Amongst others, these aspects can include enhanced agency, increased involvement in decision-making, and enriched personal growth and development. Agency includes factors like management and control over family assets, mobility outside the home, involvement in household and family decisions, and investment- and property-related decisions (Schuler et al., 2010). Entrepreneurship and business ownership can provide women with increased agency and control over their lives, which can lead to empowerment (Kantor, 2003). Women's engagement in entrepreneurial activities and contributions towards household income can lead to increased involvement in decision-making regarding family, income and household matters (Haugh 
and Talwar, 2014) and it may increase her say in issues related to reproductive health, such as child spacing and fertility (Kabeer, 2001; Mayoux and Mackie, 2007), and decisions related to their children's education and marriage, particularly for female children. They may also have greater control in decisions regarding what is spent on food, housing, clothing, medicine and leisure activities (Beath et al., 2013).

Business ownership may also encourage women to fight for their rights and against injustices perpetrated against them. By owning and managing a business, women may gain in confidence and self-esteem, which positively influences their psychological and emotional well-being (Haugh and Talwar, 2014). Moreover, despite being limited in their opportunities and resource bases, women entrepreneurs may enhance their knowledge by learning to run the business and to deal with clients and suppliers and by equipping themselves with skills like marketing, financial, leadership, management and social skills. Improvement in all these aspects of life tends to elevate their status, leading to overall development and growth for women in general (Sahab et al., 2013). Beyond knowledge and skills, entrepreneurship may also result in growth in terms of the self-perception and confidence that may motivate women to develop their businesses despite the hostile entrepreneurial environment (Haugh and Talwar, 2014).

Development economists acknowledge that value creation through enterprising has a positive impact on development indicators that go beyond economic growth, in particular for women entrepreneurs (Duflo, 2012; Minniti and Naudé, 2010). Building on this notion, in Chapter 1 Atsede Tesfaye Hailemariam, Konjit Hailu Gudeta, Brigitte Kroon and Marloes van Engen provide the narrative accounts of three women entrepreneurs in Addis Ababa, the capital city of Ethiopia, and highlight the challenges and opportunities women encounter as well as the values they create. They further explore the value that women entrepreneurs in Ethiopia create for their sense of self through their entrepreneurial activity within a constrained socio-economic environment. Specifically, their study gives an insight into how the women's entrepreneurial activities help in building capability to exercise agency, self-confidence, decision-making autonomy, well-being and personal growth and learning. Formal and informal support may strengthen the resilience of women entrepreneurs among which investing in education of girls and improving accessibility to financial loans. They further suggest that, initiatives aimed at nominating, navigating and changing constraining gender roles both for women and men may facilitate change and enhance social value creation.

In Chapter 2 Sylvia K. Gavigan, Thomas M. Cooney and Klavs Ciprikis, following the research of Bruton et al. (2013) and Tobias et al. (2013), make a case to support the argument that women engage in entrepreneurship at the grassroots level to effectively generate individual value creation, overcome poverty and to enhance their societal and economic advancement. Taking the context of rural entrepreneurship in the Kiryandongo region of North-Western Uganda, they further suggest that as productive sources in business, rural female entrepreneurs are both direct and indirect leaders in their communities who pursue a diverse range of value creation targets to support their communities (Stephan and Pathak, 2016). In trying to under- 
stand the contribution of entrepreneurship training towards perceived emancipation and value creation at an individual level, this chapter demonstrates the importance of appropriate training as a catalyst in improving business knowledge and perceived emancipation when the women make their own decisions, when they are being independent and have freedom to start their own businesses, when they support their families, achieve equality and feel capable of taking ownership of their own businesses.

In Chapter 3 Jiska de Groot, Nthabiseng Mohlakoana, Abigail Knox, Debbie Sparks and Hans Bressers remind us that while self-employment in the informal economy provides women with the independence and flexibility to balance domestic and business responsibilities, the income generated contributes to food, shelter and children's education, and many entrepreneurs express ambitions to grow their business (Fasoyiro, 2011; Knox et al. 2019). Yet, evaluations of the sector are often based only on the financial aspects of the enterprise, demonstrating the narrow conceptualization within which informal sector enterprises are assessed (Jones et al., 2017). They further argue that this approach is especially detrimental for female entrepreneurs because even though the sector is crucial for the livelihoods of many women, these informal enterprises are often inaccurately labelled as 'survivalist' enterprises that do not aspire to invest in business growth or hire staff. It is therefore often concluded that they add limited value to the economy, leading to development policies that remain fixated on monetary value creation and give priority to so-called growth-oriented enterprises. In doing so, they fail to recognize other forms of value-creation from informal entrepreneurship that extends beyond the financial gains of the enterprise. Examples of the non-monetary value added are empowerment processes and the numerous ways in which income generated through the enterprise flows back into the economy, resulting in positive social impacts, agency and self-worth, or meeting other unmet needs in society. By highlighting women's empowerment as creation of value in informal food enterprises, this chapter sets out to contribute to the evidence base, the multitude of ways in which value is created through women's entrepreneurship. Value creation, in this context refers to the success in financial and non-financial terms brought about by women's enterprises, as the value created for women by running an enterprise can encompass a range of aspects of their lives. This chapter focuses on South Africa and specifically considers the ways in which entrepreneurship in the informal sector functions as a driver of women's empowerment, proposing this as a way of creating individual value. The findings of this study show that in addition to providing a major source of income, significant additional value is created from women's entrepreneurship as their enterprises produce important empowerment benefits. These include increased capacity to make decisions, the freedom to spend income and determine one's own future, and the satisfaction and benefits that the enterprises bring to the many women who had significant reproductive responsibilities. Unlike traditional approaches to enterprise development which favour growth in firm size, profits and market penetration; this research shows that an alternative approach to development based on individual value creation linked to women's empowerment is worth pursuing. 
Despite its recent economic success, India has a significant gender imbalance in entrepreneurship, underscoring the considerable odds against female entrepreneurial success in the country. Many Indian women, nonetheless, continue to take to entrepreneurship and create significant value for themselves. In an attempt to rebalance a male-centred and wealth, profit and economic growth focused scholarly discourse in entrepreneurship, in Chapter 4 Renuka Vyas presents the narratives of individual-level value creation by four women entrepreneurs from different geographies and markets in India. These narratives shed light on the emancipatory power of entrepreneurship which sets free, constructs new meanings in lives, builds new futures and enhances the human agency of these individuals. They highlight how entrepreneurship, in conjunction with the value share focus of these women, sets in motion a value multiplier greatly benefitting their immediate families. They also show how entrepreneurship transforms these women into independent, assertive, evolved and empowered individuals. Entrepreneurship impacts them profoundly as it enhances their ability to look after their welfare as well as that of their family. Cleverly leveraging social media and positive testimonies of satisfied customers, these seemingly inconspicuous women, propelled by the power of entrepreneurship are slowly traversing their paths as independent, assertive, evolved and empowered individuals, leaving behind their unique female footprints in the Indian marketplace.

\section{Part II: Value Creation at the Business Level}

Beyond the value for the individual entrepreneur, a woman's engagement in the entrepreneurial activity can also add value to the business domain. The chapters included in Part II focus on factors such as access to resources, networks and institutional support that a female entrepreneur can accrue by being in business and gaining knowledge and experience with it.

Female entrepreneurs gain access to resources mainly by using their social networks to help identify opportunities in terms of new markets, customers, suppliers and processes that enhance value creation in business. By developing relationships with business and personal contacts, female entrepreneurs can build strong networks that can help them to serve new markets and customers. Networks can also be an integral source of financial capital for entrepreneurial women (Bruderl and Preisendörfer, 1998; Waldinger et al., 1990). Beyond social networks, human capital - the combination of education, experience and learning - can help female entrepreneurs to access resources like financing and markets. In economies where women have low levels of education and negligible experience in employment, the vicarious learning that is acquired when women gain information and knowledge from observing others, including other entrepreneurs (Santarelli and Tran, 2013; Shane, 2000), helps women sustain and develop their businesses. Learning by doing plays a significant role in enhancing entrepreneurs' intellectual development, adds to their human capital throughout the entrepreneurial process and helps them make sound decisions and take wise action in times of uncertainty (Malerba, 2007; Minniti and Bygrave, 2001; Schumpeter, 1934; Shane and Venkataraman, 2000). Therefore, even 
when women have limited access to resources, their human capital, knowledge base and social networks help them to obtain access to key resources for their businesses and so add value to their enterprises. Consequently, while an adequate resource base is a pre-requisite for entrepreneurship, the opposite may be true in the context of women's entrepreneurial activity, as women initiate an entrepreneurial idea from their homes, build, and use their networks and knowledge bases to access resources that help their businesses to grow and develop.

Women may also gain institutional support because of their entrepreneurial efforts, particularly their economic contributions through their business activities. Moreover, experience and reputation in business may help female entrepreneurs build contacts and gain access to institutional support. Differences in the context of entrepreneurial activity determine the extent of institutional access and support that women may be able to secure for their businesses. For example, women in developing countries may face strict barriers against accessing institutional support because of gendered institutions and bias in the distribution of resources among entrepreneurial actors. Moreover, the socio-cultural norms that prevail in the society may cause difficulties for women who operate within institutional voids by restricting entrepreneurial activity and, thus, the value-creation process.

In Chapter 5 Khizran Zehra, Leona Achtenhagen, Sadia Arshad, and Nadia Arshad contribute to the literature on non-economic value creation by exploring micro firms founded by female entrepreneurs in the context of adversity. The authors highlight that despite the enormous effort that entrepreneurial endeavours entail for women in adverse contexts, entrepreneurship scholars frequently portray female entrepreneurs as underperforming - focusing mainly on economic growth rather than overall value creation (Marlow and McAdam, 2013). They further remind us that this strand of literature does not always consider the complexities and gender-specific challenges that women entrepreneurs face in founding and establishing businesses in contexts that are different to the mainstream western context predominant in entrepreneurship research (Amha and Ademassie, 2004). To understand the constrained economic performance of women entrepreneurs, in relation to their broader socio-economic contexts, the authors draw upon the experiences of three ethnic Hazara women entrepreneurs from Pakistan. They outline the non-economic value created by them through collaborative activities that are typically aimed at jointly improving the life situation of Hazara women. The women entrepreneurs studied in this research displayed different types of collaborations to start and grow their ventures. These collaborations were not just effective for the women's business activities but served as a synergistic mechanism from which the different stakeholders participating in the collaboration benefitted. Their informal ventures closely work with external stakeholders to manage the flow of resources and transform these resources into exchanges between customers and suppliers. They advance a view of collaborative value creation that is informal, dynamic and recognizes the importance of non-financial value creation (i.e., entrepreneurial readiness, informal training and skill transfer, resource transferability, and cultural narrative of resilience) through 
informal training, resources and social legitimacy in constrained contextual settings (Sarfraz, 2017).

In Chapter 6 Annie Roos argues that research on entrepreneurship has a strong tendency to see value creation solely as an economic outcome, thus limiting how we envision entrepreneurship, and who is performing well, according to this standard. Women entrepreneurs almost always come out as second best in this comparison and are thus labelled as underperforming. She challenges the underperformance hypothesis surrounding women entrepreneurs by drawing upon the narratives of two women entrepreneurs from a rural Swedish community, whose experiences and successes are in direct juxtaposition with the familiar notion of the underperforming woman entrepreneur. Their stories allow us to see value created in processes that are usually neglected or missed in more conventional research and policy. Annie discusses two main observations: (1) On a business level, value accrued is used to create new value, and (2) that there is a circular flow between value adding and creating. Focusing on the business level means that the women entrepreneur interacts directly with her business, cultivating value through accumulating and creating a multiplicity of value. Focusing on both accruing and creating value, hence the process, becomes crucial in understanding how to foster further engagement with women in entrepreneurship and gender equality in regard to entrepreneurship. This cyclical relationship, when cultivating value at a business level, implies that a more holistic view of value and women entrepreneurship is needed to fully grasp the complexity of the phenomena. It highlights the fact that we can enhance value creation by focusing on accruing specific value. If the focus was solely on the value the women create, important links to how they accrued that value are missing. This chapter provides an excellent example of moving beyond the economic measures of entrepreneurship, through focusing on value as a process and not solely as an outcome.

In Chapter 7 Doaa Althalathini sheds light on the experiences of women entrepreneurs in conflict zones by exploring their value creation through engaging in entrepreneurial activities. Violent conflict can intensify conservative gender ideologies and restrict women's mobility and freedom to engage in social, political, economic and enterprise activities (Bullough and Renko, 2017). Nevertheless, women could have the opportunity to participate in economic activities and break the traditional gender roles which could lead to changes in the gendered division of the labour market. This study uses in-depth narrative interviews to elicit detailed stories with three successful women entrepreneurs in Afghanistan and Palestine. It shows that while women in such a context face additional challenges aggravated by the conflict situation such as limited resources, societal constraints, larger domestic burdens and insecurity, nevertheless, these women entrepreneurs are resourceful and they look for new opportunities to start a business or keep making changes to their business when they face a bad situation or unexpected event. In doing so, they also create value in terms of access to resources and institutional support, which enables them to sustain their business despite the challenges. Acknowledging the success of those women provides a base of knowledge upon which policies can be designed to support women's 'safe' entrepreneurship. Raising awareness regarding the programs and 
social services available to women entrepreneurs is important to the growth of their businesses. However, and due to security concerns, women could face difficulties to improve their skills and access resources even though they have intention to start a business. This reflects the importance of understanding conflict-specific challenges that women experience and integrating a gender and conflict approach to program design.

Blended value creation occurs when businesses develop social and environmental value beyond financial value, benefitting society as well as the owners of the businesses. In Chapter 8 Nadeera Ranabahu and Mary Barrett analyse narratives collected from three women entrepreneurs in rural Sri Lanka who used microfinance loans to start and develop their ventures. The results demonstrate that the women created not only economic wealth but important social-economic and economicenvironmental outcomes. They also created personal value beyond financial outcomes, improved their business processes, and created benefits for their families, employees and the wider society. While all three women valued business viability and aspired to run profitable businesses, they also clearly wanted to progress beyond survival. Training activities, although not directly linked to profit, enhanced individual skills which were later used to modify business methods. For example, they learnt to negotiate and established long-term partnerships, enabling them to better manage their raw materials and supply of finished product. They increased and diversified their customer base by attending trade exhibitions. Nadeera and Mary were surprised to see the extent to which these women were alert to social or environmental outcomes and the need to manage environmental resources responsibly (Stewardship, Eco-efficiency). For example, the entrepreneurs were concerned about the reliability of their business associations and were committed to maintaining product quality and standards. They also strived to create social legitimacy by participating in local small business association meetings, learning from and exchanging ideas with other business people. All three wanted to ensure the longevity of their businesses (sustainability). They acquired assets, hired employees, found new markets, and created new products. The authors conclude that a blended value lens produces insights into outcomes often overlooked in women-owned businesses. They suggest using entrepreneurial women's perceptions about the non-economic impacts their businesses create, such as increased personal agency and higher levels of human capital in the community, to create ways of measuring blended value. Measuring these outcomes more precisely, consistently and creatively would help public policy makers understand the true value of women entrepreneurship.

Developing countries have long focused on providing specific support to enhance women's economic development through entrepreneurship, yet this is relatively new in the Australian context. In Chapter 9 Zara Lasater, Vinita Godinho, Robyn Eversole and Naomi Birdthistle explore how, in Australia, non-traditional actors in the business support ecosystem are designing female-centric supports to empower latent entrepreneurs to self-realize as entrepreneurs, and, in so doing, to recognize the business value they generate. They remind us that the emerging scholarship exploring holistic or "multi-dimensional" business level value creation instead of the 
more restrictive notions of economic growth and financial measures of success challenges gendered assumptions and perceptions about women entrepreneurs as underperforming. In doing so, these alternative narratives of entrepreneurial success are exploring business level value created by women entrepreneurs within both developed and developing economies. In this chapter, the authors focus on women who are emerging, but not yet visible or self-identifying as entrepreneurs. They are not necessarily "reluctant" entrepreneurs; rather, their entrepreneurship is "latent". This study posits that "latent entrepreneurs" are present as entrepreneurs, but still largely invisible due to the part-time or informal nature of their entrepreneurial activities, their positioning at the margins of business support ecosystems, and their reluctance to self-identify as entrepreneurs. A grounded theory approach reveals that reframing business level value creation as social value creation is central to this actualization process, supported by three conditions: (1) Female-centric ecosystems best facilitate women entrepreneurs' access to resources, networks, and institutional support; (2) The personal knowledge and experience gained by women when supported over their business journey, empowers them to proactively build their own capabilities and help others; and (3) Being part of a "tribe" enables women to create social and economic value. The narratives reported in this study reveal a "bubbling up" of emergent female-centric ecosystems of support for "latent" women entrepreneurs in Australia, particularly those from disadvantaged and marginalized backgrounds. These ecosystems are designed to empower latent entrepreneurs to self-realize as entrepreneurs.

The public transport sector forms a large part of Kenya's informal economy in which most women work. Being a female worker in Kenya's public transport sector is challenging and it takes great resilience and persistence for the women to remain in the sector. In most cases, negative perceptions regarding women's entrance in the male dominated transport sector persist. Nevertheless, the male dominated sector is beginning to open doors for women whose entry into the sector is unearthing women's abilities. In Chapter 10 Anne Kamau and Winnie V. Mitullah provide a glimpse of women's value creation drawing from narratives of 10 women workers in the public transport sector in Kenya. The chapter explores the value that women create in public transport enterprises as own-account operators or employees. Despite limited numbers and poor working conditions, women have exploited opportunities in the sector to earn their livelihoods and are creating value at individual, business, household and societal levels. The salient presence of women workers in the transport sector is beginning to change the character of the sector and the way women are perceived in public space. Overall, women's resilient participation in the sector is challenging hegemonic notions of male dominance and societal perceptions about women's work in the public sphere and in public transport. This is driven by the fact that women are incrementally building their agency through alliances and leveraging other opportunities for upward mobility. Apart from earning income for their households, their decision-making roles are improving through participation in associational life and engagement with external actors, including unions, workers' federations and capacity-building NGOs. These external engagements advance their image as role models and impact on other women and society at large, thereby chang- 
ing the preconceived patriarchal conception of women's work. This is also increasing women's visibility in the public sphere. These connections are extending women's networks which are relevant for advancing their position not only in the transport sector but also in other spheres of life. They are able to save, leverage resources and invest in transport business, and support the survival of public transport businesses as workers. In their households they are taking care of their families, supplementing household income and changing the patriarchal conception of female gender.

\section{Part III: Value Creation at the Household and Family Level}

Value creation at the household and family level is a critical factor in explaining women's entrepreneurial development and social change. In Part III, the contributors present narrative and examples where women's engagement in entrepreneurial activities has led to significant changes in the domain of household dynamics. The positive impact of increased income from entrepreneurial activity on the household members can improve overall well-being and quality of life and improve their attitudes towards women so they are viewed as independent and entrepreneurial (Dsizi and Obeng, 2013; Haugh and Talwar, 2014; Kabeer, 2001). A woman's engagement in entrepreneurial activity may also have a positive influence on attitudes and gender roles in the household. Scholars have discussed the spill-over effects of work on family (Greenhaus and Powell, 2006), including the respect for participation in paid work (Hammer et al., 2002), improvement in women's status, sharing of domestic responsibilities, and reduced instances of genital mutilation, domestic violence and abuse, polygamy and early marriages. According to resource theory (Blood and Wolfe, 1960), access to resources like education and employment tend to be good predictors of women's participation in decision-making. Another area in which women's engagement in entrepreneurial activities can potentially add value is in women's decision-making role in the household (which we also discussed at the individual level of value creation), for example decisions related to the number of children to have, child spacing, and the use of contraception and abortion and decisions related to the children's education, choice of school and selection and timing of children's marriages (Haneef et al., 2014; Haugh and Talwar, 2014).

Nascent entrepreneurs develop their entrepreneurial identity, as part of the process of becoming entrepreneurs, through social interaction with their environments. As identity forms the basis of action, the identity of the entrepreneur provides implications for strategies and value created by new firms. In Chapter 11 Sanaa Talha and Gry Agnete Alsos examine how immigrant women entrepreneurs develop their initial entrepreneurial identities. Building upon the founder's identities framework (Fauchart and Gruber, 2011), they examine social motivations, self-assessment measures, and the frame of reference for immigrant women entrepreneurs. They conclude that immigrant women only partly relate to identity types in this framework. Their identities are more strongly linked to their concerns for their families, and they seldom focus on economic self-interest. Furthermore, many immigrant women are motivated by the needs of their ethnic community or detected problems 
in society related to immigrants or other disadvantaged groups. Based on this group of entrepreneurs, they present a refined framework to include self-/family-focused entrepreneurs, immigrant communitarians, and social missionaries.

Responding to this handbook call, in Chapter 12 Milka Kwiatek and Maria Villares-Varela address the reconceptualization of value by giving voice to UK-based migrant women entrepreneurs. They discuss how the growing attention to the contribution that migrants make tends to be slanted towards their financial return, while overlooking their influence on job creation, cushioning competition with native workers, and setting role models for migrant communities. They further point out how the gender-blindness of the field concealed patriarchal domination sustaining the ethnic economy. Drawing on four in-depth biographical narratives and a selection of participants' produced photographs, this study provides an academic platform for migrant women entrepreneurs to express their experiences of entrepreneurship and value creation. This chapter presents the voices of migrant women entrepreneurs in the UK in relation to the impact of their ventures on creating a meaningful input beyond the economic dividend. Although migrant businesses are generally characterized by being of small size and located in what is considered "low low value" activities, the authors argue that these assumptions are based on a circumscribed conceptualization of value creation. Narratives of the interviewees and their visual production show how becoming a businesswoman in the ethnic economy can be seen as a means of leadership in the community, solidarity with other women entrepreneurs and generating value beyond the economic dividend for both British society and countries of origin, in the realms of production and reproduction.

The final chapter in this section is contributed by Vahid Makizadeh, Shumaila Yousafzai, Siavash Aein Jamshid and Marzieh Nasiri. They propose that despite institutional constraints female entrepreneurs in Iran experience their entrepreneurial activities as a source of value for themselves and other stakeholders, especially their family. Drawing upon the narrative reports of female entrepreneurs in Bandarabbas, the capital city of Hormozgan province in the south of Iran, Based on the notion that the authors put forward the argument that beyond economic values, female entrepreneurs in Iran create immense values for the family including positive intra-family dynamics, the positive impact of female income on the family members, and change of attitudes towards females, who may now be perceived as an agent of change. The authors also suggest that ethics of care and enacting a supportive role for all family members in females can enhance desired family values such as respect, love, and empathy. In other words, these female entrepreneurs' traits create a favourable family atmosphere around female entrepreneurs that finally lead to deeper positive emotions in the family.

\section{Part IV: Value Creation at the Societal Level}

Female entrepreneurs can become agents of social change by promoting the society's overall development and growth through entrepreneurship. Social outcomes in this regard pertain to local community development through increased employment for 
the local population (Birch, 1979; Haugh, 2006) and providing and increasing the choice of goods and services that meet the community's needs. In societies with strict religious and traditional norms that restrict a woman's mobility outside the home, a female-based enterprise like a health service may be a significant source of services to other women in the community, thus contributing to value creation at the community level.

The impact of women's entrepreneurship at the societal level has been discussed in several research domains, including those of economic vitality, stability and the availability of goods and services. In terms of social impact, the society's security, values, attitudes, lifestyles and norms may be influenced. Furthermore, addition of value in terms of contributing to the community's overall development and growth may include increased well-being, raising the quality of life, creating employment, promoting gender equality and improving satisfaction with life (Haugh and Talwar, 2014; Nicholls, 2009; Welter and Xheneti, 2015; Zahra and Wright, 2015). Women's entrepreneurial activity can also change the perceptions of and attitudes towards women in a society, resulting in greater support for female entrepreneurs. These changes include influencing gender norms and traditions, enhancing the status of and respect for women in the society, and inculcating positive motivation to become entrepreneurs and increase their independence in others through role models (Haugh and Talwar, 2014; Mayoux and Mackie, 2007).

In the presence of social constraints on women in a society, entrepreneurship can bring about social change by empowering women to fight for their rights and to change gendered assumptions about women. Through entrepreneurial efforts, women can show that they can be agents for social change and justify their increased freedom and mobility. They may exercise agency, have control over their life decisions and overcome societal resistance to pursue their goals in their personal and professional lives. Moreover, women in business can increase society's respect and recognition of women (Haugh and Talwar, 2014). Similarly, women may influence gendered institutions in their entrepreneurial environments because of their entrepreneurial efforts and contributions to value in their societies. In this regard, women may gain access to entrepreneurial resources from institutions that were once available only to male entrepreneurs. Being in business can also help women gain knowledge about the ways of doing business, the rules and regulations regarding business activity in various markets and strategies with which to overcome institutional voids. Entrepreneurship empowers women and enables them to overcome injustices that may hamper business performance and affect their personal lives (Kabeer, 2001; Mayoux and Mackie, 2007; Tankard and Paluck, 2016; Zahra and Wright, 2015).

There has been a great deal written and said about the barriers and challenges that Arab women entrepreneurs face. However, studies that attempt to explore and understand the importance of women entrepreneurs as agents of change in Arab society, including how they deliver and support value-creation activities, are noticeably scarce. In Chapter 14 Hayfaa Tlaiss explores the unique ways in which Saudi Arabian women entrepreneurs create value within a constrained, patriarchal society. In doing so, she challenges mainstream studies that focus only on obstacles. Instead, 
she celebrates Arab women's agency and acknowledges their success as value creators. Her findings demonstrate how entrepreneurial success is a subjective concept within which entrepreneurs have their own understanding and conceptualizations of what success means to them. The women in this study assessed their entrepreneurial success from within broader perspectives, whereby they factored in their conceptualizations of value creation at the societal level. They portrayed personal agency and capitalized on a feminist perspective to Islamic teachings in order to construct their own entrepreneurial identity within a conservative, masculine context rather than accepting patriarchal interpretations. These women negotiated their entrepreneurial choices and navigated through religious and patriarchal societal structures and constraints. In doing so, they created value at the societal level through being role models for young women and agents for change in Saudi society. Hence, Hayfaa proposes that Arab women, even those operating within a dominant masculine patriarchy, have agency and the ability to emancipate themselves and give their entrepreneurial ventures and activities an alternative meaning that is based on value creation and success.

Research has consistently shown that the informal economy provides alternative means to livelihoods and reduces poverty, offers a creative and transitional space to test capability, and is a vehicle for social mobility amongst the urban poor (Adom and Williams, 2012; Gough et al., 2003; Langevang and Gough, 2012; Timilsina, 2011). In Chapter 15 Mirela Xheneti and Shova Thapa Karki explore how informal women entrepreneurs in a developing country context create value through nurturing social relations in their communities. Focusing on the rich narratives of three women entrepreneurs in three cities in Nepal, they illustrate the richness of life experiences and the economic and socio-cultural characteristics with implications for societal value creation. Particularly, they highlight three different ways through which women entrepreneurs are creating value - by changing perceptions about women's work, supporting other women in the community by providing employment opportunities, and acting as role models in their communities. By focusing on a narrative approach, the authors are able to make visible the processes through which these different societal value outcomes were achieved. A processual view of value creation allows to understand how women's agency develops over time together with the constraints and enablers of this agency.

Along the lines of the theme of this volume, in Chapter 16 Ruta Aidis highlights the important economic and social contribution made by female entrepreneurial activities. Ruta points out that previous studies often focus on solo women entrepreneurs and the benefits accrued to them and their communities. In her chapter, she expands on the blended value conceptual framework and explores the significant non-financial value that is created by women entrepreneurs for women as their employees or as women workers. The six women entrepreneurs, all small and medium-size enterprise owners profiled in this chapter, operate in diverse sectors and country contexts in the Americas and exemplify a blended value approach highlighting a broader range of value creation through entrepreneurship beyond economic gains. All show that added value for women (as employees and workers) can be compatible with successful business development. Ruta's findings support the female oriented value system of 
the ethics of care that focuses on the interconnectedness among parties involved and nurturing behaviour. The issues addressed in each of the six case studies of women entrepreneurs operating in the Americas vary, ranging from specific safety needs for women workers and supporting working mothers re-entering the workforce to providing an inclusive business model that focuses on "quality of life" and gender equity in male-dominated sectors. Yet an overarching commonality in these case studies is the commitment to providing added value as part of their everyday business operations. They are all examples of a blended values approach to entrepreneurship and their added value activities are related to the ethics of care, a nurturing behaviour towards other women, which supports the notion of a female oriented value system introduced by Gilligan (1982). Ruta suggests that working together with the media, governments should increase awareness and visibility of the instrumental role SMEs play in providing additional value to women workers as a strategy to incentivize additional SMEs to adopt similar practices.

In the unique context of South Africa, where entrepreneurs see opportunity in social needs spawned by apartheid, Ethné Swartz, Caren Scheepers and Frances Amatucci in Chapter 17 contribute to the discussion on value creation by extending our understanding on how women entrepreneurs in South Africa create value at the societal level and how the South African political and historical context influences this value creation. Using illustrative case studies of four employer firms across a range of industries, they discuss how social value creation began with women exerting influence on the content of the constitution that enshrines legal and property rights for women. The authors further explore how these women create new institutional forms by seizing on regulatory system changes to build investment companies for financial inclusion. This mindset is vital to how "shared value" is perceived in countries undergoing fundamental transformations. At the cognitive and the normative levels, these female entrepreneurs demonstrate the agency and choice required to create opportunities for previously disadvantaged groups by offering jobs in hospitality, digital services, education, and facilities management. They have also influenced the normative system by providing new role models and setting new gender role expectations through scaling and growing companies. Overall, this chapter offers a deeper understanding of the human agency contribution of women and points to a heightened awareness of women's role in democratic change in South Africa. The authors have successfully managed to demonstrate how South Africa's political and historical context created the environment for the emergence of these women-founded enterprises that contribute to a multiplier effect of social value creation. Government and policy makers should note the important role of women entrepreneurs, and offer encouragement and recognition for their efforts, and where appropriate, funding to assist in scaling their services.

For more than three decades, studies on women's entrepreneurship have focused on cisgender heterosexual male and female entrepreneurs who act within narrowly gendered spaces (Al-Dajani et al., 2015; Marlow and Martinez Dy, 2018). Thus, the call by mainstream scholars for equality between men and women in entrepreneurial spaces has focused on the conventional binary of the two genders at the expense 
of others. Others are considered to be an "out-group" of gender identities, such as gay, lesbian, transgender, asexual, intersex, and queer - all of which are quite often excluded from mainstream visibility in discussions of gender and entrepreneurship (Marlow and Martinez Dy, 2018). In Chapter 18, Roshni Narendran highlights the need to go beyond the socially accepted binary sexes when considering female entrepreneurship. In culturally rich countries like India, the transgender community faces barriers which prevent them from breaking free from the socially assigned roles for men and women. Even though India has a long history with the transgender community, there are still reports of abuse. In this chapter, Roshni shares insights into two transgender women entrepreneurs in South India who create social value to help others who, despite the bullying and discrimination against their nonconforming gender and sexual identities, have created successful enterprises in South India and provided platforms to fight against discrimination, showcase their talent, and develop skill sets, all of which help to bring the transgender community into the mainstream. This chapter examines the process by which they identified opportunities through witnessing and experiencing harassment and shows how this provided them with knowledge and access to stakeholders to create social value for others in the community. It shows how disclosing their gender identity gave them an opportunity to build resilience to create and share value with other members of the community. Members of the transgender community face many problems; however, it is important to understand how such barriers contribute to their resilience and the creation of social value for other members of the community. This is one of the few works within the scholarship on female entrepreneurship that moves beyond the mainstream studies of male and female entrepreneurs.

As discussed in previous chapters, value creation is central to any discussion on entrepreneurship. For the most part these discussions focused on the potential economic impact, particularly job creation, innovation and new business development. The emergence of research in the area of female entrepreneurship in the 1980s suggests that any discussion on value creation needs to move beyond this traditional economic model to include a broader societal value creation approach. The emergence of the Millennial generation has reignited the debate on value creation and entrepreneurship, as this new generation of young and technologically savvy individuals have a stronger motivation towards social responsibility and making an impact on the world. In Chapter 19 Angela Hamouda, Kate Johnston and Rebecca Nevins provide new insights into this new cohort of entrepreneurs and the implications for the development of appropriate training and supports. The authors envisage that this new wave of entrepreneurs are challenging our typical view of entrepreneurs and in turn are calling into question the supports needed to encourage growth among this cohort.

In Chapter 20 Hans Lundberg proposes to reconceptualize the idea of social value creation as social constraint alleviation. Hans refers to social as the limitations of a system that keep it from attaining its goal, system refers to systems consisting of people (i.e., a specific social stratum) and social constraint alleviation is based on the distinction between organizations that bypass or exploit a social constraint 
and organizations that absorb it. Hans argues that this distinction is fundamental, as according to Sinkovics et al. (2015, p. 341), organizations "that design their business models in such a way that their day-to-day operations absorb a social constraint [...] achieve a significant development impact on the communities in which they are embedded". His second main argument is that it is not enough to consider only the internal system of an organization and its stakeholders; equally needed is to be able to measure, estimate, analyze and compare social value creation on societal level. Following a case study approach, Hans focuses on data from an under-represented geographical context (Mexico) and highlights the importance of women entrepreneurs as social value creators with high societal impact. The findings highlight that women entrepreneurs generate value via leadership traits normally assigned to women (i.e., dialogical, relational, relating, authentic, caring). It further provides insight into the art of complexity reduction via management of paradoxes by women entrepreneurs. Hans concludes that social value is something tangible emanating out of concrete practices, rather than an abstraction or "something fluffy".

Conflict destroys infrastructure, damages the social fabric, and drives down socio-economic strength of individuals. In the context of post-conflict countries, entrepreneurship seems to be the best option for countries to tie their hopes for accelerated economic development In Chapter 21 Musarrat Jabeen and Shandana Sheikh investigate the experiences of women entrepreneurs in a post-conflict development context by exploring their value creation at the individual and society level through the narrative accounts of two women entrepreneurs in Swat, Pakistan. The authors suggest that women entrepreneurs create value by realizing enhanced entrepreneurial intentions, entrepreneurial skills and experiencing greater recognition in the community as an entrepreneur by virtue of their skills and capability. The women entrepreneurs moved their businesses to counter anti-women empowerment militant organizations. The results of this research identify women entrepreneurs as a significant source of value creation in the under-researched contexts of post conflict development and militancy. Accordingly, it highlights the knowledge on entrepreneurship in post conflict development context; so that the state and society can build sustainable peace based on women entrepreneurship.

\section{MOVING FORWARD}

The process of value creation depends on the environment in which it is created (Zahra et al., 2009). While some policies support women in business, most are targeted at high-growth and profit-oriented businesses (Aslund and Bäckström, 2015) and ignore the micro-women entrepreneurs who may not be high-profit-oriented but may be important contributors of social value. Concluding the discussion from the previous sections, the chapters presented in this edited volume present the case that the contexts in which entrepreneurs operate present them with unique challenges, so an entrepreneur's performance should be judged from a broad environmental perspective. Knowledge of the context helps to define a need or entrepreneurial 
idea that can result in an outcome of value. More important, legitimization of value is a key aspect in it being validated across the public sphere, for all concerned agents. Authorization of value through women's entrepreneurial activity is a key to its creation and facilitation. Such authorization entails a double responsibility: to legitimize women entrepreneurs, such as those in the informal economy and micro businesses, and to legitimize the multiple aspects of value that result from such activity. Efforts are required across a variety of frontiers to achieve this goal. For example, governments can play an active role in validating, recognizing and appreciating the value outcomes of women entrepreneurs in creating public value. As for the business sector, it can support women by providing support services, including business skills, training and financing. The non-profit sector and the community can also play an active role in legitimizing the value of women entrepreneurs. Through their businesses, women meet the needs of their communities and add value to it, so appreciation of women's entrepreneurial efforts by fellow community members, citizens, and household and family members can encourage women to become more entrepreneurial.

\section{CLOSING REMARKS}

We extend a special thanks to Edward Elgar and its staff, who have been most helpful throughout this entire process. We also warmly thank all of the authors who submitted their manuscripts for consideration for this book. They showed their desire to share their knowledge and experience with the book's readers and a willingness to present their research and their views for possible challenge by their peers. We also thank the reviewers, who provided excellent independent and incisive consideration of the anonymous submissions.

We hope that this compendium of chapters and themes stimulates and contributes to the ongoing debate surrounding the contextual embeddedness of women-owned enterprises. The chapters in this book can help to fill some gaps in what we know while stimulating further thought and action.

\section{REFERENCES}

Adom, K. and Williams, C.C. (2012). Evaluating the motives of informal entrepreneurs in Koforidua, Ghana. Journal of Developmental Entrepreneurship, Vol 17(1), p. 1250005.

Ahl, H. (2006). Why research on women entrepreneurs needs new directions. Entrepreneurship Theory and Practice. Vol 30(5), pp. 595-621. doi:10.1111/j.1540-6520.2006.00138.x.

Al-Dajani, H., Carter, S., Shaw, E. and Marlow, S. (2015). Entrepreneurship among the displaced and dispossessed: Exploring the limits of emancipatory entrepreneuring. British Journal of Management, Vol 26(4), pp. 713-730.

Amha, W. and Ademassie, A. (2004). Rural financial intermediation program and its role in strengthening the rural financial system in Ethiopia. Journal of Microfinance Development Review, Vol 3(2), 230-365. 
Aslund, A. and Bäckström, I. (2015). Creation of value to society - a process map of the societal entrepreneurship area. Total Quality Management \& Business Excellence, Vol 26, pp. 385-399.

Audretsch, D.B., Keilbach, M.C. and Lehmann, E.E. (2006). Entrepreneurship and Economic Growth. New York: Oxford University Press.

Baumol, W.J. (1986). Entrepreneurship: Productive, unproductive, and destructive. Journal of Business Venturing, Vol 11(1), pp. 3-22.

Beath, A. Christia, F. and Enikolopov, R. (2013). Empowering women through development aid: Evidence from a field experiment in Afghanistan. American Political Science Review, Vol 107(3), pp. 540-557.

Birch, D.G. (1979). The Job Generation Process. Cambridge, MA: MIT Program on Neighborhood and Regional Change.

Blood, R.O. and Wolfe, D.M. (1960). Husbands and Wives. New York: Free Press.

Bruderl, J. and Preisendörfer, P. (1998). Network support and the success of newly founded businesses. Small Business Economics, Vol 19, pp. 213-225.

Bruton, G.D., Ketchen Jr, D.J. and Ireland, R.D. (2013). Entrepreneurship as a solution to poverty. Journal of Business Venturing, Vol 28, pp. 683-689.

Bullough, A. and Renko, M. (2017). A different frame of reference: Entrepreneurship and gender differences in the perception of danger. Academy of Management Discoveries, Vol 3(1), pp. 21-41.

Dsizi, S. and Obeng, F. (2013). Microfinance and the socio-economic wellbeing of women entrepreneurs in Ghana. International Journal of Business and Social Research, Vol 3(11), pp. 45-62.

Duflo, E. (2012). Women empowerment and economic development. Journal of Economic Literature, Vol 50(4), pp. 1051-1079.

Fasoyiro, S.B. (2011). Assessment of hazards in local soy-cheese processing: Implications on health and environment in Oyo state, Nigeria. WIT Transactions on Ecology and the Environment, Vol 152, pp. 37-44.

Fauchart, E. and Gruber, M. (2011). Darwinians, communitarians, and missionaries: The role of founder identity in entrepreneurship. Academy of Management Journal, Vol 54 (5), pp. 935-957.

Gilligan, C. (1982). In a Different Voice. Cambridge, MA: Harvard University Press.

Gough, K.V., Tipple, G. and Napier, M. (2003). Making a living in African cities: The role of home-based enterprises in Accra and Pretoria. International Planning Studies, Vol 8(4), pp. $253-277$.

Greenhaus, J.H. and Powell, G.N. (2006). When work and family are allies: A theory of workfamily enrichment. Academy of Management Review, Vol 31(1), pp. 72-92.

Hammer, L.B., Cullen, J.C., Caubet, S., Johnson, J., Neal, M.B. and Sinclair, R.R. (2002). The Effects of Work-Family Fit on Depression: A Longitudinal Study. Paper presented at the 17 th Annual Meeting of SIOP, Toronto.

Haneef, C., Pritchard, M., Hannan, M., Kenward, S., Rahman, M. and Alam, Z. (2014). Women as entrepreneurs: The impact of having an independent income on women's empowerment. http://www.enterprise-development.org/wp-content/uploads/Women-as-Ent repreneurs_The-impact-of-having-an-independent-income-on-womens-emp owerment August-2014.pdf. Accessed on 20 February 2020.

Haugh, H. (2006). Social enterprise. Beyond economic outcomes and individual returns. In Mair, J., Robinson, J., and Hockerts, K. (eds), Social Entrepreneurship. New York: Palgrave Macmillan, pp. 180-205.

Haugh, H.M. and Talwar, A. (2014). linking social entrepreneurship and social change: The mediating role of empowerment. Journal of Business Ethics, pp 1-16. 
Jones, P., Jones, A. and Williams-Burnett, N. (2017). Let's get physical: Stories of entrepreneurial activity from sports coaches/instructors. International Journal of Entrepreneurship and Innovation, Vol 18(4), pp. 219-230.

Kabeer, N. (2001). Conflicts over credit: Re-evaluating the empowerment potential of loans to women in rural Bangladesh. World Development, Vol 29(1), pp. 63-84.

Kantor, P. (2003). Women's empowerment through home-based work: Evidence from India. Development and Change. Vol 34(3), pp. 425-445.

Knox, A.J., Bressers, H., Mohlakoana, N. and De Groot, J. (2019). Aspirations to grow: When micro- and informal enterprises in the street food sector speak for themselves. Journal of Global Entrepreneurship Research, Vol 9(1), p. 38.

Korsgaard, S. and Anderson, A.R. (2011). Enacting entrepreneurship as social value creation. International Small Business Journal, Vol 29(2), pp. 135-151.

Langevang, T. and Gough, K.V. (2012). Diverging pathways: Young female employment and entrepreneurship in sub-Saharan Africa. The Geographical Journal, Vol 178(3), pp. $242-252$.

Malerba, F. (2007). Innovation and the dynamics and evolution of industries: Progress and challenges. International Journal of Industrial Organization, Vol 25, pp. 675-699.

Marlow, S., Carter, S. and Shaw, E. (2008). Constructing female entrepreneurship policy in the UK: Is the US a relevant benchmark? Environment and Planning C: Government and Policy, Vol 26(2), pp. 335-351.

Marlow, S. and Martinez Dy, A. (2018). Annual review article: Is it time to rethink the gender agenda in entrepreneurship research? International Small Business Journal, Vol 36(1), pp. 3-22.

Marlow, S. and McAdam, M. (2013). Gender and entrepreneurship: Advancing debate and challenging myths; exploring the mystery of the under-performing female entrepreneur. International Journal of Entrepreneurial Behavior \& Research, Vol 19(1), pp. 114-124. https://doi.org/10.1108/13552551311299288.

Mayoux, L. and Mackie, G. (2007). Guide to gender integration in value chain development, "making the strongest links". International Labour Organization. http://www.ilo .org/wcmsp5/groups/public/@ed_emp/@emp_ent/documents/instructionalmaterial/wcms 106538.pdf. Accessed on 19 August 2020.

McMullen, J.S. and Warnick, B. (2015). The downside of blended value and hybrid organizing. Journal of Management Studies, Vol 53(4), pp. 630-662.

Minniti, M. and Bygrave, W. (2001). A dynamic model of entrepreneurial learning. Entrepreneurship Theory and Practice, Vol 25, pp. 5-16.

Minniti, M. and Naudé, W. (2010). What do we know about the patterns and determinants of female entrepreneurship across countries? European Journal of Development Research, Vol 22, 277-293.

Nicholls, A. (2009). We do good things, don't we? Blended value accounting in social entrepreneurship. Accounting, Organizations and Society, Vol 34(6), pp. 755-769.

Powell, G.N. and Eddleston, K.A. (2008). The paradox of the contented female business owner. Journal of Vocational Behavior, Vol 73(1), pp. 24-36.

Sahab, S., Thakur, G. and Gupta, P.C. (2013). A case study on empowerment of rural women through micro entrepreneurship development. Journal of Business Management, Vol 9(6), pp. 123-126.

Santarelli, E. and Tran, H.T. (2013). Growth of incumbent firms and entrepreneurship in Vietnam. University of Bologna - Department of Economics Working Paper \# 785.

Sarfraz, H. (2017). A restaurant in Quetta's Hazara Town is by women, for women, The Express Tribune, 13 November 2017, https://tribune.com.pk/story/1534555/1-a-restaurant -in-hazara-town-is-for-women-by-women/. Accessed on 13 December 2019.

Schuler, S.R., Islam, F. and Rottach, E. (2010). Women's empowerment revisited: A case study from Bangladesh. Development in Practice, Vol 20(7), pp. 840-854. 
Schumpeter, J.A. (1934). The Theory of Economic Development: An Inquiry into Profits, Capital Credit, Interest and the Business Cycle. Cambridge, MA: Harvard University Press.

Shane, S. (2000). Prior knowledge and the discovery of entrepreneurial opportunities. Organization Science, Vol 11(4), pp. 448-469.

Shane, S. and Venkataraman, S. (2000). The promise of entrepreneurship as a field of research. Academy of Management Review, Vol 25(1), pp. 217-226.

Sinkovics, N., Sinkovics, R.R., Hoque, S.F. and Czaban, L. (2015). A reconceptualisation of social value creation as social constraint alleviation. Critical Perspectives on International Business, 11 (3/4), 340-363.

Stephan, U. and Pathak, S. (2016). Beyond cultural values? Cultural leadership ideals and entrepreneurship. Journal of Business Venturing, Vol 31(5), pp. 505-523.

Tankard, M.E. and Paluck, E.L. (2016). Norm perception as a vehicle for social change. Social Issues and Policy Review, Vol 10(1), pp. 181-211.

Timilsina, K.P. (2011). An urban informal economy: Livelihood opportunity to poor challenges for urban governance. Global Journal of Human Social Science, Vol 11(2), 25-31.

Tobias, J.M., Mair, J. and Barbosa-Leiker, C. (2013). Toward a theory of transformative entrepreneuring: Poverty reduction and conflict resolution in Rwanda's entrepreneurial coffee sector. Journal of Business Venturing, Vol 28(6), pp. 728-742.

Vossenberg, S. (2013). Women entrepreneurship promotion in developing countries: What explains the gender gap in entrepreneurship and how to close it? file:///Users/ shandanasheikh/Downloads/MSM-WP2013-08\%20(7).pdf. Accessed on 5 April 2020.

Waldinger, R.D., Aldrich, H. and Ward, R. (1990). Ethnic Entrepreneurs: Immigrant Business in Industrial Societies. Newbury Park, CA: Sage.

Welter, F. (2011). Contextualizing entrepreneurship - conceptual challenges and ways forward. Entrepreneurship Theory and Practice, Vol 35(1), pp. 165-184.

Welter, F. and Xheneti, M. (2015). Value for whom? Exploring the value of informal entrepreneurial activities in post-socialist contexts. Exploring Criminal and Illegal Enterprise: New Perspectives on Research, Policy and Practice, Vol 5, pp. 253-275.

World Economic Forum. (2012). Global gender gap report. http://www3.weforum.org/docs/ WEF_GenderGap_Report_2012.pdf. Accessed on 12 May 2020.

Zahra, S.A., Gedajlovic, E., Neubaum, D.O. and Shulman, J.M. (2009). A typology of social entrepreneurs: Motives, search processes and ethical challenges. Journal of Business Venturing, Vol 24, pp. 519-532.

Zahra, S.A. and Wright, M. (2015). Understanding the social role of entrepreneurship. Journal of Management Studies, Vol 53(4), pp. 610-629. 